\title{
A CASE OF RENal FaIlure AND OSTEOSCLEROSIS
}

BY

RONALD F. FLETCHER,* B.Sc., M.D., M.R.C.P.

AND

\begin{abstract}
ALASTAIR C. FRAZER, M.D., D.Sc., F.R.C.P.
From the Department of Medical Biochemistry and Pharmacology, University of Birmingham, and the Metabolic Research Unit, Little Bromwich General Hospital, Birmingham
\end{abstract}

[With Special Plate]

Chronic azotaemic renal failure is often accompanied by changes in the skeleton which include (alone or in combination) rickets, osteomalacia, and osteitis fibrosa (Stanbury, 1957). The bones are usually of decreased over-all density with irregular denser areas which do not follow the normal architecture (Fourman, 1960). Rarely, there is a more extensive osteosclerosis, particularly involving the spine and skull (Crawford et al., 1954 ; Wolf and Denko, 1958 ; Kaye et al., 1960). The cause of this osteosclerosis is not known, and the number of patients with this condition who have been studied in detail is small.

\section{Case Report}

A 40-year-old housewife first attended hospital three and a half years before her death with pain in the right chest. A radiograph showed a fractured rib, which was treated by strapping. A year later she complained of pain on the other side, but no fracture was found. Six months afterwards she complained of more pain, and the urine, previously normal, contained albumin.

On admission her chief complaints were of low central backache, pains in both sides of the chest, and tiredness. Her past medical history was not remarkable. Her diet had been adequate; she had drunk $1 \frac{1}{2}$ pints ( 0.85 litres) of milk a day for many years. Her height was $161.5 \mathrm{~cm}$. and she weighed $45 \mathrm{~kg}$. The mucous membranes were pale but otherwise normal. There was a slight generalized brown pigmentation of the skin. A systolic murmur was heard at the cardiac apex, and the blood-pressure was $160 / 90 \mathrm{~mm}$. Hg. Apart from wasting of fat and muscles, there were no other physical signs.

\section{Investigations}

Azotaemia with a hyperchloraemic acidosis and a normochromic, normocytic anaemia were present. The serum level of calcium was extremely low, and that of phosphorus only slightly raised (see Table). White cell count 5,000 per c.mm. with a normal differential. The serum protein electrophoretic strip was normal ; $58 \%$ of the serum calcium was diffusible. The total serum carotenoids were $155 \mu \mathrm{g}$. per $100 \mathrm{ml}$. (normal $90 \pm 30 \mu \mathrm{g}$.), and vitamin A 205 i.u. per $100 \mathrm{ml}$. (normal $105 \pm 20$ i.u.)

The urine contained about $5.0 \mathrm{~g}$. of protein per day, but the amino-acid chromatogram was normal; slight glycosuria was detected once. The urine ammonia averaged $14 \mathrm{mEq}$ per day. Urinary excretion of chloride was about $10 \mathrm{mEq}$ per day more than that of sodium. This relationship was maintained, within a few milliequivalents, for total excretions of $50-120 \mathrm{mEq}$ per day. Only when the urine volume fell below 1.5 litres per day was salt output restricted. However, the volume of the urine seemed to be the main determinant of potassium excretion, because the concentration of potassium in the urine varied only between 15 and $25 \mathrm{mEq} / 1$., in random fashion, with urine volumes of

*Present address: Department of Medicine, Queen Elizabeth Hospital, Birmingham 15 .
0.6-3.0 litres per day. The serum creatinine was $5.1 \mathrm{mg}$. per $100 \mathrm{ml}$. and the creatinine clearance $15.2 \mathrm{ml}$. per minute. The urine specific gravity was always 1008 to 1011 even when vasopressin was injected. The urine contained an excess of white cells $\left(360 \times 10^{\circ}\right.$ per day) and a few red cells $\left(6 \times 10^{6}\right.$ per day), and Escherichia coli was cultured from it several times. An intravenous pyelogram failed to show excretion. Only the left ureter could be catheterized. The pattern of the left calices was normal, but the thickness of the renal parenchyma was reduced.

The urinary calcium excretion was low at $14 \mathrm{mg}$. per day. Over 15 days calcium balance was positive $(620 \mathrm{mg}$. per day; intake $1,030 \mathrm{mg}$. per day) and the phosphorus balance was also positive (300 mg. per day). A calcium infusion test (Nordin and Fraser, 1956) showed a "fourhour skeletal retention" of $85 \%$ of the dose (normal $50-60 \%$ ) and a 12 -hour urinary loss of $2 \%$ (normal 33-53\%). An intravenous injection of 400 units of "para-thor-mone," from a batch of proved activity, caused no change in the serum calcium level. An intravenous injection of about $60 \mu \mathrm{c}$. of radioactive calcium $\left({ }^{47} \mathrm{Ca}\right.$; half-life 4.9 days) was given and the radioactivity in the serum, stools, and urine measured for the next 12 days. As calculated by the methods of Heaney and Whedon (1958), the total exchangeable calcium was $3.2 \mathrm{~g}$., or $67 \mathrm{mg}$. per $\mathrm{kg}$. body weight. The boneformation rate was $520 \mathrm{mg}$. Ca per day, or $10.8 \mathrm{mg}$. per $\mathrm{kg}$. body weight. The serum citrate was $2.3-3.1 \mathrm{mg}$. per $100 \mathrm{ml}$. (normal 1.5-4.0 mg.), but the urine citrate was only $64 \mathrm{mg}$. per day (normal 300-1,200 mg.). When citrate was given by mouth the urinary excretion rose to $220 \mathrm{mg}$. per day.

The basal metabolic rate was $-12 \%$ and the uptake of ${ }^{131}$ I in the neck at 24 hours was $35 \%$ of dose (normal $30-60 \%$ ). After thyrotrophin (T.S.H.) was injected the uptake was $42 \%$ of dose (normal $50-60 \%$-Fletcher and Besford, 1958). An intravenous sugar tolerance test showed a rate of fall of blood sugar of $1.8 \%$ per minute (normal $1.5 \%$-Ikkos and Luft, 1957). The urinary excretion of 17-ketosteroids at $2 \mathrm{mg}$. per day and that of 17-ketogenic steroids at $1 \mathrm{mg}$. per day were low. The plasma corticoids, also low, were $<1 \mu \mathrm{g}$. per $100 \mathrm{ml}$. A normal response followed the administration of corticotrophin (A.C.T.H.) gel, 40 units eight-hourly for six doses intramuscularly, the urine containing $17 \mathrm{mg}$. per day of 17 -ketosteroids and $80 \mathrm{mg}$. per day of 17 -ketogenic steroids.

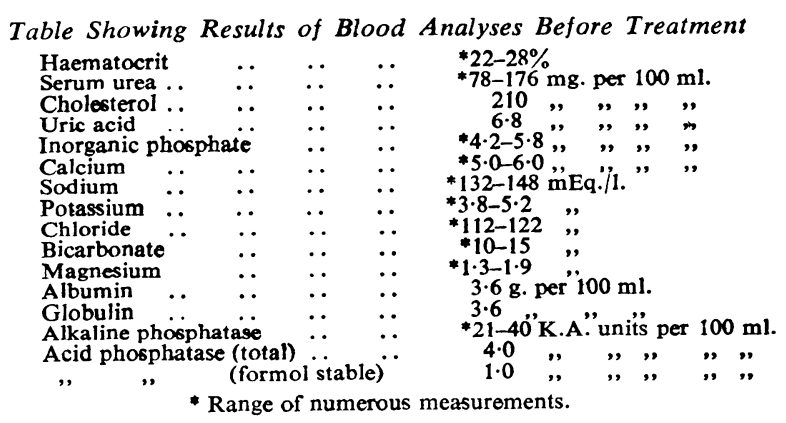

Radiological examination showed increased bone opacity and thickened trabeculae in most of the skeleton. In the vertebrae (see accompanying radiograph) the sclerosis had advanced from both end-plates almost to obliterate the central cancellous bone. The skull, pelvis, and femora were sclerosed, but the changes below the elbows and knees were less marked. The lamina dura was normal in some areas and deficient in others. A bone biopsy was taken from the iliac crest (Sacker and Nordin, 1954). The bone was very hard and the cortex was not penetrated at a depth of $6 \mathrm{~mm}$. (normal 3-4 $\mathrm{mm}$. for a middle-aged woman). Microscopically, the bone was dense and lamellar in structure, with an increased number of cement lines in a mosaic which tended to be regular. Under polarized light the fibrillar pattern of the bone was regular and parallel with the lamellae. Active apposition with a superficial layer 
of osteoblasts was present in some areas, but osteoclastic resorption was not seen.

\section{Progress}

After investigation the patient was treated with cortisone acetate by mouth, $25 \mathrm{mg}$. per day, as replacement therapy, and sodium citrate, $100 \mathrm{mEq}$ per day. The latter only partially corrected the acidosis, but the serum calcium level fell to $3.8 \mathrm{mg}$. per $100 \mathrm{ml}$. (repeated estimations), causing neither overt nor latent tetany, nor other ill effects. Dihydrotachysterol (AT10), $10 \mathrm{ml}$. per day, was given, and the serum calcium rose slowly to $6.0 \mathrm{mg}$. per $100 \mathrm{ml}$. After one month the AT10 was stopped, and the serum calcium remained at about $5.0 \mathrm{mg}$. per $100 \mathrm{ml}$. A course of oral tetracycline was given. The patient's symptoms diminished and during the next year she led a fairly normal life, having the same treatment. Oral aluminium hydroxide, in an attempt to

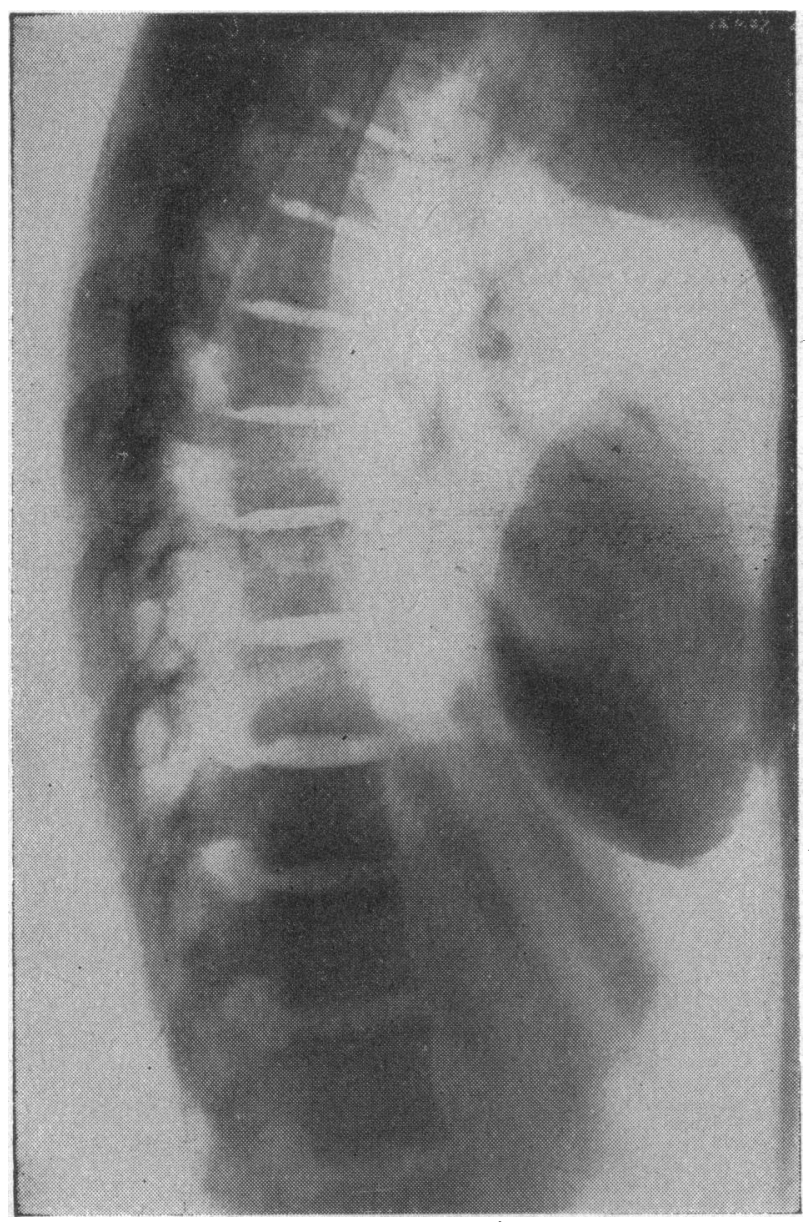

Radiograph of spine.

reduce the phosphate retention, and, later, magnesium hydroxide to correct the low serum magnesium level, had no effect on the general condition and renal function. The radiographic appearance of the bones was unchanged. The blood urea level rose slowly and she died in oliguric renal failure.

\section{Necropsy Findings}

The heart showed left ventricular hypertrophy and slight rheumatic mitral stenosis. The left kidney weighed $60 \mathrm{~g}$. ; the surface was granular, the capsule adherent, and the cortical markings undefined. Histologically there was generalized scarring and fibrosis. Focal infiltration with polymorphonuclear granulocytes was more marked in the medulla than the cortex. Most of the glomeruli showed ischaemic changes with periglomerular fibrosis. A few nephrons were relatively undamaged and showed compensatory hypertrophy. The changes were those of chronic nephritis, possibly secondary to chronic pyelonephritis (Special Plate, Fig. 1). The right kidney was represented by a small cyst $1 \mathrm{~cm}$. across attached to an attenuated but patent ureter.

The pituitary and adrenal glands appeared normal. The thyroid was small, and only one small parathyroid gland was found despite a careful search. All these glands were histologically normal. The osteosclerosis of the skull, iliac crest, and femur was confirmed, but the ribs were only slightly abnormal. The iliac crest bone (Special Plate, Fig. 2) showed the same histological appearances as were found 18 months previously. In addition to the decalcified sections, a preparation was made using the method of Lillie (1954), and it could be seen that there were large amounts of uncalcified osteoid tissue present showing as unstained areas around the Haversian canals (Special Plate, Fig. 3). Nothing else of interest, apart from terminal changes, was noted at necropsy.

\section{Discussion}

The radiological diagnosis of osteosclerosis is easily missed. In the present instance at least five observers failed to recognize the osteosclerosis in the earlier films, taken to show certain ribs, though in retrospect the spine showed marked changes. There were two lesions in the bones. The histological appearances suggested an increased osteoblastic activity which, being opposed by little or no osteoclastic resorption, had led to a great increase in the total mass of bone matrix. Though the total skeletal burden of calcium was increased, the positive calcium balance had been inadequate and the whole bone sections showed wide osteoid seams.

The nature of the renal disease is uncertain, but the changes in the blood were those expected in chronic renal failure. The calcium infusion test showed a high skeletal avidity for calcium consistent with the histological appearances. The total exchangeable calcium was slightly reduced (Heaney and Whedon, 1958), but the "bone-formation rate" of $520 \mathrm{mg}$. per day was normal and agrees well with the positive calcium balance, assuming that no calcium was being liberated from the bones.

The very low corticoid excretion with a normal response to exogenous A.C.T.H. indicates that there was a failure of A.C.T.H. production, but the normal menses and thyroid function imply good gonadotrophin and T.S.H. production. Similar unexplained A.C.T.H. failure has been found in otherwise normal subjects (Steinberg et al., 1954 ; Perkoff et al., 1960) and in a malnourished woman (Fletcher and Brown, 1959).

Osteosclerosis in adults has been reported in association with hyperparathyroidism (Davies et al., 1956; Beveridge et al., 1959), fluorine intoxication (Stevenson and Watson, 1957), and alkali ingestion (Rifkind et al., 1960), and also in a family with a history of osteosclerosis (Montgomery and Standard, 1960), but much more commonly associated with renal failure, as in the present case. The causation of the osteosclerosis remains obscure.

\section{Summary}

A case of chronic azotaemic renal failure and gross generalized osteosclerosis in a 41-year-old woman is described. Uncalcified osteoid tissue was present in the sclerotic bone and there was a positive calcium and phosphorus balance. The parathyroid glands had failed to respond to the very low serum calcium level. There was a failure of A.C.T.H. production with otherwise good pituitary function. 
. Treatment resulted in a diminution of symptoms, but had no effect on the renal function or the radiographic appearance of the bones, and she died a year later in oliguric renal failure. The post-mortem findings are described.

We wish to thank the many persons who assisted in the accumulation of the data about this patient, particularly Dr. H. G. Sammons, Dr. W. F. R. Pover, and the late Dr. A. H. Henley. We would also thank Dr. R. D. Blachford for referring the patient, and Professors J. W. Orr and D. H. Collins and Drs. J. Hardwicke and W. Whitelaw for pathological reports.

REFERENCES

Beveridge, B., Vaughan, B. F., and Walters, M. N. I. (1959). J. Fac. Radiol. (Lond.), 10, 197. Crawford, T., Dent, C. E., Lucas, P., Martin, N. H., and
Nassim, J. R. (1954). Lancet, 2. 981.

Davies, D. R., Dent, C. E., and Willcox, A. (1956). Brit. med. J., 2,1133
Fletcher, R. F and Besford, H. (1958), Clin, Sci, 17, 113. - and Brown, P. S (1959). Ibid., 18, 367 .

Fourman, L. P. R. (1960). Calcium Metabolism and the Bone Blackwell, Oxford.

Heaney, R. P., and Whedon, G. D. (1958). J. clin. Endocr., 18 1246 .

Ikkos, D., and Luft, R. (1957). Acta endocr. (Kbh.), 25, 312

Kaye, M., Pritchard, j. E., Halpenny, G. W., and Light, W. (1960). Medicine (Baltimore), 39, 157 .

Lillie, R. D. (1954). Histopathologic Technic and Practical Histochemistry, 2nd ed. Blakiston, New York.

Montgomery, R. D., and Standard, K. L. (1960). J. Bone Jt Surg., $42 \mathrm{~B}, 303$.

Nordin, B. E. C.. and Fraser, R. (1956). Lancet, 1, 823, 826

Perkoff, G. T., Eik-nes, K., Carnes, W. H., and Tyler, F. H. (1960). J. clin. Endocr., 20, 1269.

Rifkind, B. M., Chazan, B. I., and Aitchison, J. D. (1960). Bris med. J., 1, 317 .

Sacker, L. S., and Nordin, B. E. C. (1954). Lancet, 1, 347.

Stanbury, S.'W. (1957). Brit. med. Bull., 13, 57.

Steinberg, A., Schechter, F. R., and Segal, H. I. (1954). J. clin. Endocr., 14. 1519.

Stevenson, C. A., and Watson, A. R. (1957). Amer. J. Roentgenol. 78,13 .

Wolf, H. L., and Denko, J. V. (1958). Amer. J. med. Sci., 235

\section{FATAL MYOCARDIAL SARCOIDOSIS}

BY

\author{
GHBERT FORBES, M.D., B.Sc., F.R.F.P.S. \\ F.R.C.S.Ed. \\ Reader in Charge
}

ALAN USHER, M.B., B.S. Lecturer

Department of Forensic Medicine, University of Sheffield

\section{[With Special Plate]}

Schaumann $(1914,1917)$ first postulated the modern concept of sarcoidosis as a systemic granuloma, probably infective in origin, presenting a pleomorphic clinical picture according to its sites of attack in the body. In about $80 \%$ of cases the process is self-limiting and the patient recovers. Often the disease is an incidental finding. Death from sarcoidosis most frequently results from heart failure-cor pulmonale usually developing secondary to extensive pulmonary sarcoidosis or its residual fibrosis. More rarely sarcoid is found invading the heart directly and embarrassing its action by massive replacement of heart muscle by non-contractile tissue or by interruption of the conducting mechanism. Occasionally it causes valvulitis (Laroche et al., 1955) or pericarditis (Gilg, 1953).

Since Bernstein et al. (1929) reported finding epicardial sarcoid granulomata in a patient dying of pneumonia, all degrees of cardiac infiltration have been described. Involvement of the heart is to be found in about $20 \%$ of all cases of disseminated sarcoidosis (Freiman, 1948 ; Longcope and Freiman, 1952). In many of these cases the cardiac lesion has remained clinically silent, the patient dying from some other manifestation of the disease or from some unrelated condition (Skavlem and Ritterhoff, 1946 ; Hauser, 1946 ; Spencer and Warren, 1938 ; Longcope, 1941). In a few instances the circulatory disturbance produced by cardiac involvement has proved to be of a transitory nature and recovery has followed (Longcope and Fisher, 1941; Moyer and Ackerman, 1950; Gold and Cantor, 1959). There remains a group of cases where myocardial sarcoidosis has led directly to a fatal issue. Probably the first death of this sort was recorded by Longcope and Fisher in 1941. Adickes et al. (1951) had the distinction of recording the first case of myocardial sarcoidosis to be diagnosed in life and subsequently confirmed at necropsy.

Various associated cardiac arrhythmias have been the subject of several excellent papers (Salveson, 1935;
Riley, 1950 ; Gold and Cantor, 1959 ; Porter, 1960), and the electrocardiographic findings in myocardial sarcoidosis have been described by Leitner (1946), Salveson (1935), McCort et al. (1947), and others. Criteria for the histological diagnosis have been firmly established by Nickerson (1937), Bates and Walsh (1948), and Yesner and Silver (1951).

Since 1941 we have collected from the literature (see Table) 24 cases where myocardial sarcoidosis is considered by us to be the lesion primarily and directly responsible for death. We wish to add to these a case of our own.

\section{Case Report}

A white male steelworker aged 44 first presented as an out-patient complaining of increasing shortness of breath and of backache radiating round to the precordial area. There was no significant previous medical history.

On examination at this time the pulse was 86 per minute and regular, and the blood-pressure was $100 / 60 \mathrm{~mm}$. $\mathrm{Hg}$. The heart was slightly enlarged; there was no audible murmur, but a triple rhythm was heard and there were bilateral basal crepitations. The rest of the examination was negative. A tentative diagnosis of myocardial infarction in early congestive heart failure was made and subsequent electrocardiogram was reported by Dr. R. S. Weetch as follows: "Sinus rhythm, P-R interval $0.22 \mathrm{sec}$. Occasional ventricular extrasystoles, spread of $Q R S$ complex indicative of interventricular block. Flattened $T$ waves in the first and second limb leads with a raised S-T segment in lead 3. S-T depressed leads V4-6 and T inverted." This record was highly abnormal, and, although not specifically diagnostic of infarction. it was thought to be compatible with it in view of the history and physical findings. The patient was accordingly admitted to hospital, where his general condition improved but his blood-pressure remained low; he developed right bundle-branch block, and after three weeks he was discharged home.

No clinical records of his progress at home are available, but he is said to have led a careful life and did not again complain of chest or back pain. Fifteen days after his 


\section{R. F. FLETCHER AND A. C. FRAZER: RENAL FAILURE AND OSTEOSCLEROSIS}

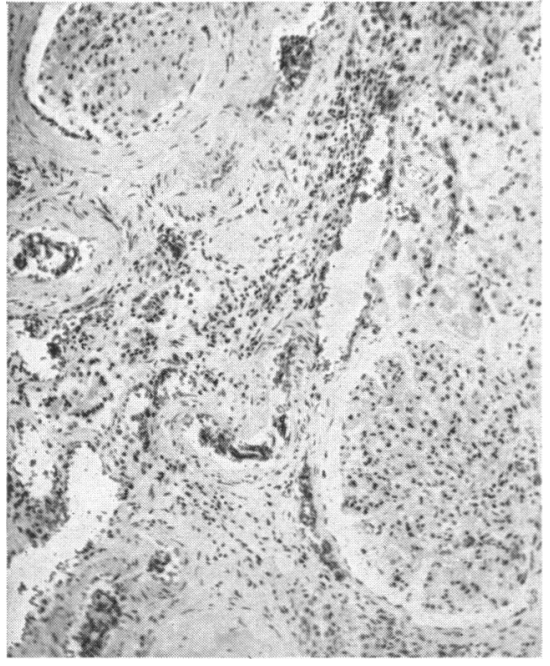

Fig. 1.-Histological appearance of left kidney at necropsy. (H. and E. $\times 60$.)

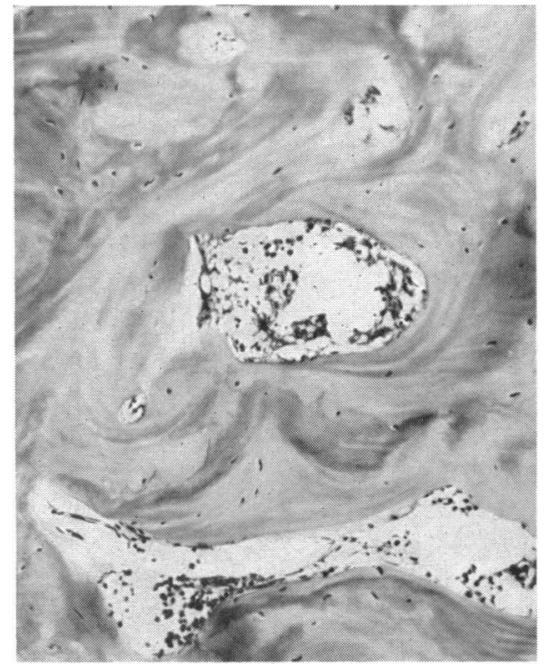

FIG. 2.-Histological appearance of iliac crest bone at necropsy. (H. and E.

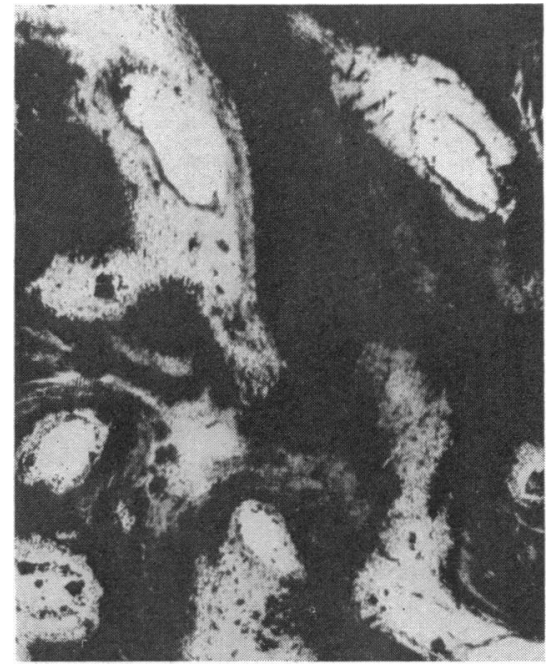

FIG 3-Iliac crest bone at necropsy. (Lillie preparation. $\times 60$.) Black areas indicate calcified tissue, except that centres of trabeculae cannot be stained with this technique.

L. WOLMAN: CEREBRAL DAMAGE IN WHOOPING-COUGH

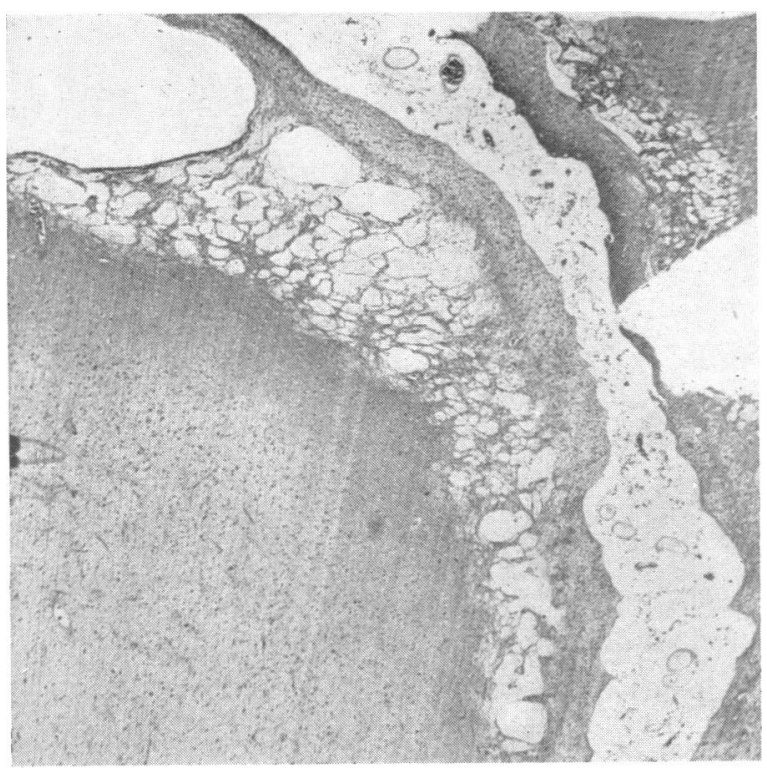

FIG. 1

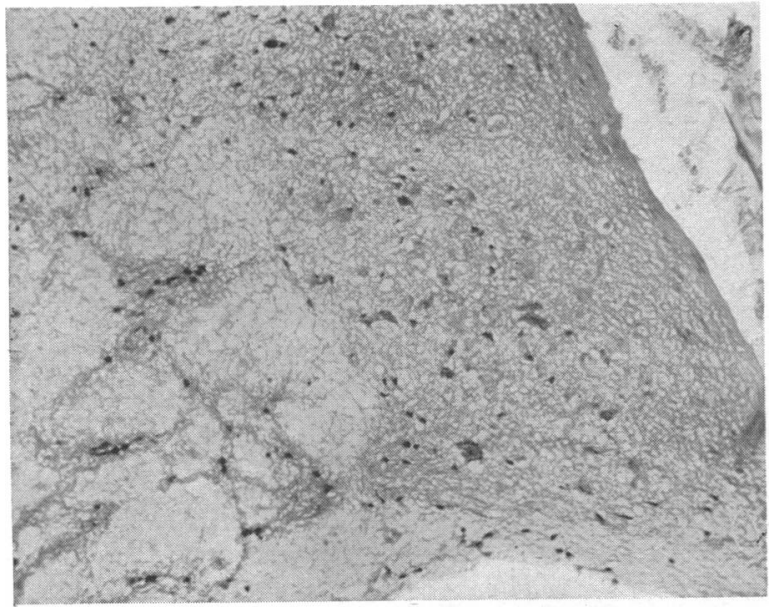

FIG. 3

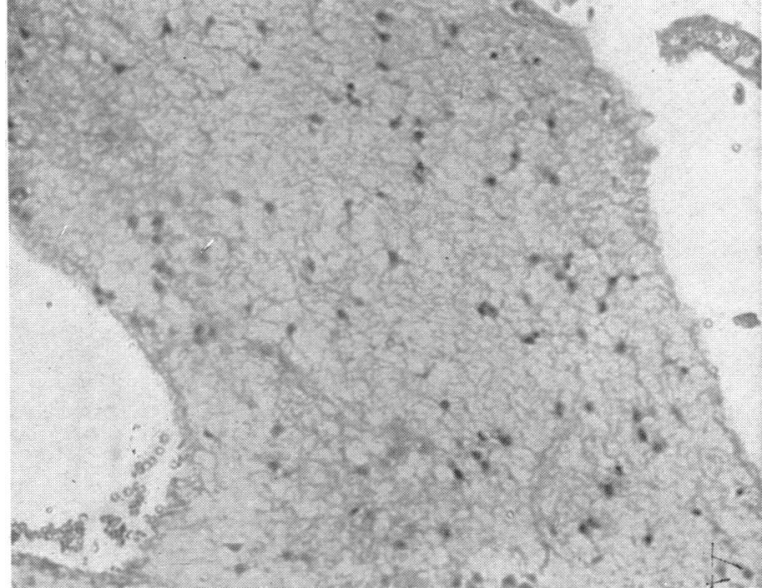

FIG. 2

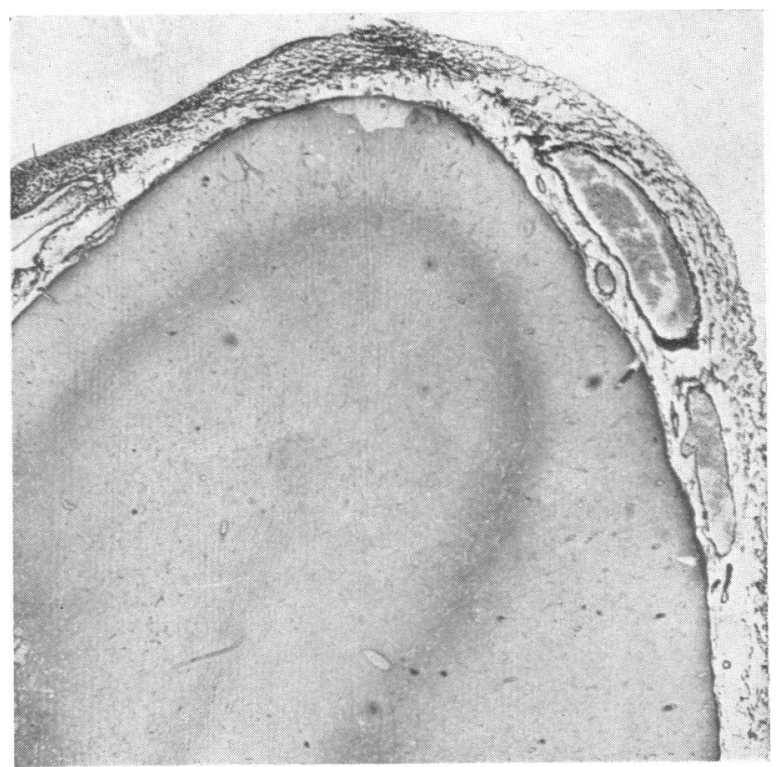

Fig. 4 